\title{
ЛУБЯНЫЕ ВОЛОКНА - НОВЫЕ ВОЗМОЖНОСТИ ДЛЯ «ЗЕЛЕНОЙ» НАНОТЕХНОЛОГИИ
}

\author{
Н. С. Дымникова, Е. В. Ерохина, А. П. Морыганов \\ НАТАЛЬЯ СЕРГЕЕВНА ДЫМНИКОВА - кандидат технических наук, научный сотрудник лаборатории \\ «Химия и технология модифицированных волокнистых материалов» ИХР РАН. Область научных \\ интересов: синтез наночастии металлов, биологически активные материалы медицинского и технического \\ назначения. E-mail: nsd@isc-ras.ru.
}

ЕКАТЕРИНА ВЯЧЕСЛАВОВНА ЕРОХИНА - кандидат химических наук, младиий научный сотрудник лаборатории «Химия и технология модифицированных волокнистых материалов» ИХР РАН. Область научных интересов: комплексоны в синтезе биологически активных нанокомпозитов и при химической модификации природных полимеров.E-mail: erochina2007@yandex.ru.

АНДРЕЙ ПАВЛОВИЧ МОРЫГАНОВ - доктор технических наук, профессор, заведуюший лабораторией «Химия итехнологиямодифицированныхволокнистыхматериалов» ИХР РАН. Область научныхинтересов: химическая модификация природных полимеров, новые волокнистые материаль для текстильной промышленности.E-mail: apm@isc-ras.ru.

153045 , г. Иваново, ул. Академическая, д. 1. Федеральное государственное бюджетное учреждение науки Институт химии растворов им. Г.А. Крестова Российской академии наук.

Методом «зеленого» синтеза получены наночастииы серебра. Изучен прочесс формирования наночастии серебра в экстрактах из лубяных (конопляного и льняного) волокон. Установлена зависимость эффективности процесса восстановления ионов серебра от количественного содержания примесей в экстракте. Методом фотонной коррелячионной спектроскопии определены размеры образуюшихся частии. Доказано, что антимикробная активность в отночении тест-культур синтезированных золей и обработанной ими целлюлозной ткани зависит от условий проведения синтеза.

Ключевые слова: серебро, экстракты, лубяные волокна, синтез, целлюлозные волокна, антимикробная активность.

\section{BAST FIBERS - NEW OPPORTUNITIES FOR "GREEN" NANOTECHNOLOGY}

\author{
N.S. Dymnikova, E. V. Erohina, A.P. Moryganov \\ 1, Akademicheskaya St., Ivanovo, 153045, Russia. Federal Government Institution of Sciences G.A. Krestov Institute \\ of Solution Chemistry of the Russian academy of Sciences.
}

Silver nanoparticles were obtained using the "green" synthesis method. The process of formation of silver nanoparticles in extracts from bast (hemp and flax) fibers was studied. The relationship between the efficiency of the silver ion reduction process and the quantitative content of impurities in the extract was established. The sizes of the resulting particles were determined by photon correlation spectroscopy. It is proved that the antimi- 
crobial activity of synthesized sols and cellulose tabric treated with this Sol in relation to test cultures depends on the conditions of synthesis.

Keywords: silver, extracts, bast fibers, synthesis, cellulose fibers, antimicrobial activity.

\section{Введение}

В последнее десятилетие наблюдается экспоненциальный рост в фундаментальных и прикладных областях науки, связанный с синтезом наночастиц благородных металлов, изучением их свойств и практическими применениями. Одним из перспективных направлений использования НЧ является получение биологически активных текстильных материалов. Это изделия для медицины, гигиены, защитные ткани, одежда для активного образа жизни и для профилактики микозных заболеваний.

Успехи в научном исследовании и использовании наночастиц металлов в значительной мере зависят от возможностей методов синтеза - от того, позволяет ли выбранный метод получать частицы, удовлетворяющие требованиям данной научной или практической задачи. При этом одной из важнейших проблем является синтез достаточно стабильных наночастиц заданного размера, в течение длительного времени сохраняющих высокую химическую или биологическую активность.

Особого внимания заслуживают благородные металлы подгруппы $\mathrm{Cu}$, в частности серебро. $\mathrm{Ce}$ ребро, в отличие от органических (химических) консервантов и дезинфектантов, - природный элемент, не загрязняющий природу. Это - экологически чистый, «зеленый» продукт. Являясь сильным биоцидом для микробов и вирусов, серебро, в отличие от других металлов, в то же время гораздо менее токсично для многоклеточных организмов [1]. В последние десятилетия в связи с широким использованием антибиотиков и химических консервантов ускоряется процесс появления резистентных штаммов возбудителей болезней у людей, тогда как серебро не создает резистентных штаммов, подавляя возбудителей на 100 \% и не давая им мутировать и размножаться.

Однако не следует забывать, что серебро относится к тяжелым металлам, а эти металлы токсичны. Поэтому очень многое зависит от вида, состава, концентрации, дозы НЧ металлов, условий и способа их применения. Известно, что хорошо растворимые соли серебра обладают бактерицидным, противовирусным, выраженным противогрибковым и антисептическим действием, но, в тоже время, имеют и высокую реакционную способность, оказывают прожигающее и раздражающее действие на кожу и слизистые [2]. Кроме того, ионы серебра инактивируются при связывании с хлорид-, фосфат- и другими анионами жидких сред организма и клеточных компонент, образуя нерастворимые и/или малоактивные соединения [3]. Данное обстоятельство привело к разработке более безопасных и безвредных форм серебряных препаратов, а именно коллоидного и кластерного серебра (наносеребра). Они имеют чрезвычайно большую удельную площадь поверхности, что увеличивает область контакта серебра с бактериями или вирусами, значительно улучшая его бактерицидные действия. Согласно исследованиям, для того, чтобы убить одинаковое количество бактерий, ионов серебра в растворе нужно в 100 раз больше, чем наночастиц. Поэтому даже маленькое содержание наночастиц в продукте способно обеспечить очень серьёзный эффект [1].

Наиболее перспективными и приемлемыми для практического применения являются способы химического восстановления солей серебра в присутствии природных высокомолекулярных соединений (растительных экстрактов и in vitro культур растений), так называемый «зеленый синтез». Известно [4], что растительный мир производит огромное количество низко- и высокомолекулярных веществ (спирты, полисахариды, белки и т.д.), обладающих redox-потенциалом и способных восстанавливать катионы диссоциирующих солей металлов. Авторами цитированных работ доказано, что восстановление ионов до нульвалентного состояния осуществляется концевыми альдегидными, карбоксильными и спиртовыми группами экстрагируемых из растений полисахаридов, которые появляются в результате химической деструкции макромолекул. При этом эти вещества способны выступать одновременно как коллоидные стабилизаторы высокодисперсных систем. Более того, обладая собственной биологической, а иногда и физиологической активностью, природные полимеры снижают токсичность металлов, сообщают им лечебные свойства.

Этот способ имеет ряд преимуществ перед химическими методами, главными из которых являются мягкие условия синтеза и отсутствие в конечном растворе более или менее ядовитых побочных продуктов или примесей, поскольку биовосстановители являются нетоксичными, дружественными природе и биологически разлагаемыми.

Среди природных полисахаридов наиболее известен арабиногалактан, выделенный из древесины 
лиственницы сибирской, в которой он содержится в количестве $10-15 \%$. Особые свойства данного биополимера - это низкая токсичность, высокая растворимость в воде, уникально низкая вязкость растворов, узкое молекулярно-массовое распределение, а также биоразлагаемость [5]. Аналогичный результат зарегистрирован для экстрактов из листьев Aloe Vera, Brassica juncea, Lavandula angustifolia, березы, крапивы, цветов ромашки, плодов шиповника и др. [6-10].

Интересной нам представляется возможность использования при формировании НЧ серебра экстрактов лубяных волокон, а именно льна и конопли. Ранее нами было установлено [11], что экстрагируемые из лубяных культур соединения способны обеспечивать агрегативную устойчивость коллоидных растворов серебра, а при создании необходимых условий участвовать и в окислительно-восстановительных процессах. Более того, сопутствующие льняной целлюлозе высокомолекулярные соединения могут снижать токсичность используемых металлов, повышать их лечебное действие. Это указывает на целесообразность применения волокон льна при получении экологически чистых биологически активных нанокомпозитов широкого спектра действия.

Цель данной работы заключалась в оптимизации условий получения стабильных гидрозолей металлического серебра в присутствии экстрактов лубяных волокон и оценке целесообразности их применения для обеспечения целлюлозосодержащим материалам антимикробной активности или биозащищенности.

\section{Экспериментальная часть}

\section{Получение экстрактов и синтез наночастич серебра}

Экстракты лубяных волокон получали путем обработки механически очищенного волокна раствором гидроксида натрия $\left(5-25 \cdot 10^{-2}\right.$ моль/л) при температуре $40-100{ }^{\circ} \mathrm{C}$ в течение $30-60$ минут в жидкостном термостате. В качестве лубяных волокон использовали: короткое льноволокно номер 3 , полученное со льноперерабатывающего завода Омской области «Знаменский лен» и промышленный сорт однодомной конопли «Диана» (среднерусский экотип), произведенный в фермерском хозяйстве Симанщино (Пензенская обл.). Данный сорт конопли относится к «безнаркотическим», поскольку содержание в нем психотомиметически активного каннабиноидного соединения ТГК составляет 0,011-0,020 \% (норма - не выше $0,1 \%$ ).

Содержание лигнина в волокне определяли сернокислотным методом согласно ГОСТ 11960-79.
Содержание пектиновых веществ определяли весовым методом [12], гемицеллюлоз - согласно методике, описанной в [13].

Синтез наночастиц серебра осуществляли реакцией химического восстановления нитрата серебра $\left(0,6 \cdot 10^{-2}\right.$ моль/л) в водных растворах экстракта лубяного волокна в открытой термостатируемой ячейке при температуре $90 \pm 2{ }^{\circ} \mathrm{C}$. Синтезированные золи хранили в закрытых колбах.

\section{Приборы и методы анализа наночастии серебра}

Окислительно-восстановительный потенциал экстрактов лубяных волокон определяли на автоматическом титраторе АТП-02 с использованием платинового электрода в качестве измерительного электрода и хлорсеребряного в качестве электрода сравнения при температуре $20-100{ }^{\circ} \mathrm{C}$ в условиях термостатирования.

Процесс формирования высокодисперсных частиц контролировали визуально по изменению окраски растворов и их агрегативной устойчивости, а также спектрофотометрически.

Оптические спектры поглощения Ag-гидрозолей регистрировали в области 300-500 нм на спектрофотометре СФ-56 фирмы Ломо-спектр (С.-Пб) в кварцевой кювете, длина оптического слоя -1 см.

Распределение частиц металла по размерам в растворе оценивали методом динамического рассеяния света на приборе «Zetasizer nano ZS» фирмы "Malvern".

\section{Тесты на антибактериальную активность и биозащчищенность материалов}

Оценку антимикробной активности синтезированных золей серебра и целлюлозной ткани, обработанной золями, проводили методом диффузии в агар на твёрдой среде, согласно ГОСТ ISO 206452014. На подготовленный бактериальный газон, засеянный соответствующими тест-культурами, помещали золь с НЧ серебра или образцы отбелённой х/б ткани, обработанные синтезированным золем. Чашки Петри в течение суток выдерживали в термостате при температуре $37 \pm 2{ }^{\circ} \mathrm{C}$. Для количественной оценки степени воздействия биоцидов измеряли зону ингибирования роста тест-культур вокруг лунок или образцов с нанесенным препаратом в мм.

Биодеструкцию текстильных материалов после выдерживания их в почвенной микрофлоре в течение 10 суток оценивали визуально по изменению их внешнего вида, согласно ГОСТ 9.060.

В качестве объекта для защиты от биодеструкторов использовали ткань Брезент арт. 7 поверх- 
ностной плотностью 500 г/м² ные (не подвергавшиеся действию химических реагентов) волокна льна и хлопка. Текстильный материал пропитывали золями серебра в течение 10 мин при температуре $30 \pm 1{ }^{\circ} \mathrm{C}$, отжимали на лабораторной плюсовке до остаточного содержания раствора $100 \%$ и высушивали на воздухе. Устойчивость объектов к биоразрушению оценивали в условиях, благоприятных для развития естественного комплекса микрофлоры, под которым следует понимать сообщество микроорганизмов, развивающихся на растительных волокнах в процессе их роста, а также сорбирующихся на текстильных материалах в процессе их обработки и хранения.

\section{Результаты и обсуждение}

\section{Синтез ультрадисперсных частии серебра в экстракте из лубяных волокон}

Общим для лубяных волокон является наличие в их составе целлюлозы (72-80 \% от массы волокна) и сопутствующих веществ различной природы (см. табл. 1).

Таблииа 1

Химический состав лубяных волокон $[14,15]$

\begin{tabular}{lcc}
\hline \multirow{2}{*}{$\begin{array}{c}\text { Основные компоненты } \\
\text { волокна }\end{array}$} & $\begin{array}{c}\text { Содержание, } \\
\text { \% абсолютно сухому } \\
\text { волокну }\end{array}$ \\
\cline { 2 - 3 } Целлюлоза & $72-80$ & $72-78$ \\
Лигнин & $3,5-5,0$ & $5,2-6,2$ \\
Пектиновые вещества & $2,0-4,5$ & $4,0-6,7$ \\
Жировые и воскообраз- & $2,0-3,0$ & $0,6-1,4$ \\
ные вещества & & \\
Гемицеллюлозы & до 10 & до 10 \\
Азотсодержащие & $1,9-2,1$ & $1,6-2,0$ \\
вещества & & \\
Зольные вещества & $0,8-1,1$ & $0,8-1,0$ \\
Прочие & до 2,3 & до 0,5 \\
\hline
\end{tabular}

Необходимые для восстановительного процесса альдегидные, карбоксильные и спиртовые группировки содержатся в естественных спутниках целлюлозы лубяных культур: пектиновых соединениях, гемицеллюлозе и лигнине, большая часть которых ( 70 \%) дислоцирована в срединных пластинках, соединяющих элементарные волокна (см. табл. 2).

Необходимым этапом облагораживания лубяных волокон перед белением или крашением (после механического разволокнения и очистки) явля- ется извлечение этих спутников в процессе отварки (химической очистки от примесей и модификации) волокнистой массы. Как правило, варочный раствор с экстрагируемыми примесями направляется в стоки.

Из литературных источников известно, что основные примеси наиболее эффективно растворяются и удаляются из волокна при щелочной обработке сурового механически очищенного волокна, где в качестве щелочного реагента используется гидроксид натрия [16]. Сорбция щелочи волокном обеспечивает протекание процессов ее взаимодействия с примесями, вызывает глубокие трансформации в их структуре, что, в итоге, способствует извлечению примесей из волокна.

Экстракцию примесей из предварительно очищенного от костры и промытого сурового волокна проводили в растворе гидроксида натрия концентрации 2-10 г/л. Увеличение концентрации щелочного агента в варочном растворе выше 10 г/л нецелесообразно во избежании существенной элементаризации волокна в результате быстрого разрушения срединных пластинок. Кроме того, значительная часть гидроксида натрия будет оставаться в растворе, что нерационально как с экологической, так и с экономической точки зрения [17].

На рис. 1 приведена диаграмма, характеризующая количественный выход примесей в экстракт из волокнистой массы после обработки ее щелочными растворами.

В конопляном волокне действие гидроксида натрия распространяется, главным образом, на примеси углеводного характера - гемицеллюлозы, которые практически полностью удаляются при сильнощелочной химической обработке. В льняном волокне их остается довольно много около 30 \%. Значительная часть кислотонерастворимого лигнина Класона (48-60 \%) даже при высокой концентрации щелочи остается в конопляных волокнах, препятствуя растворению срединных пластинок и дроблению комплексного волокна. Напротив, лигнин льняного волокна проявляет меньшую устойчивость к щелочному гидролизу и при обработке раствором щелочи 10 г/л льняное волокно теряет $64 \%$ лигнина.

Половина пектиновых веществ экстрагируется из льняного волокна даже при минимальной концентрации гидроксида натрия, а при увеличении содержания щелочи до 10 г/л эти вещества практически полностью переходят в экстракт. Из пеньковых волокон даже при высокой концентрации щелочного агента переходит в раствор только 60-65\% пектинов.

Таким образом, для максимальной экстракции природных примесей из лубяных волокон необхо- 
Основные структурные формулы примесей лубяных культур

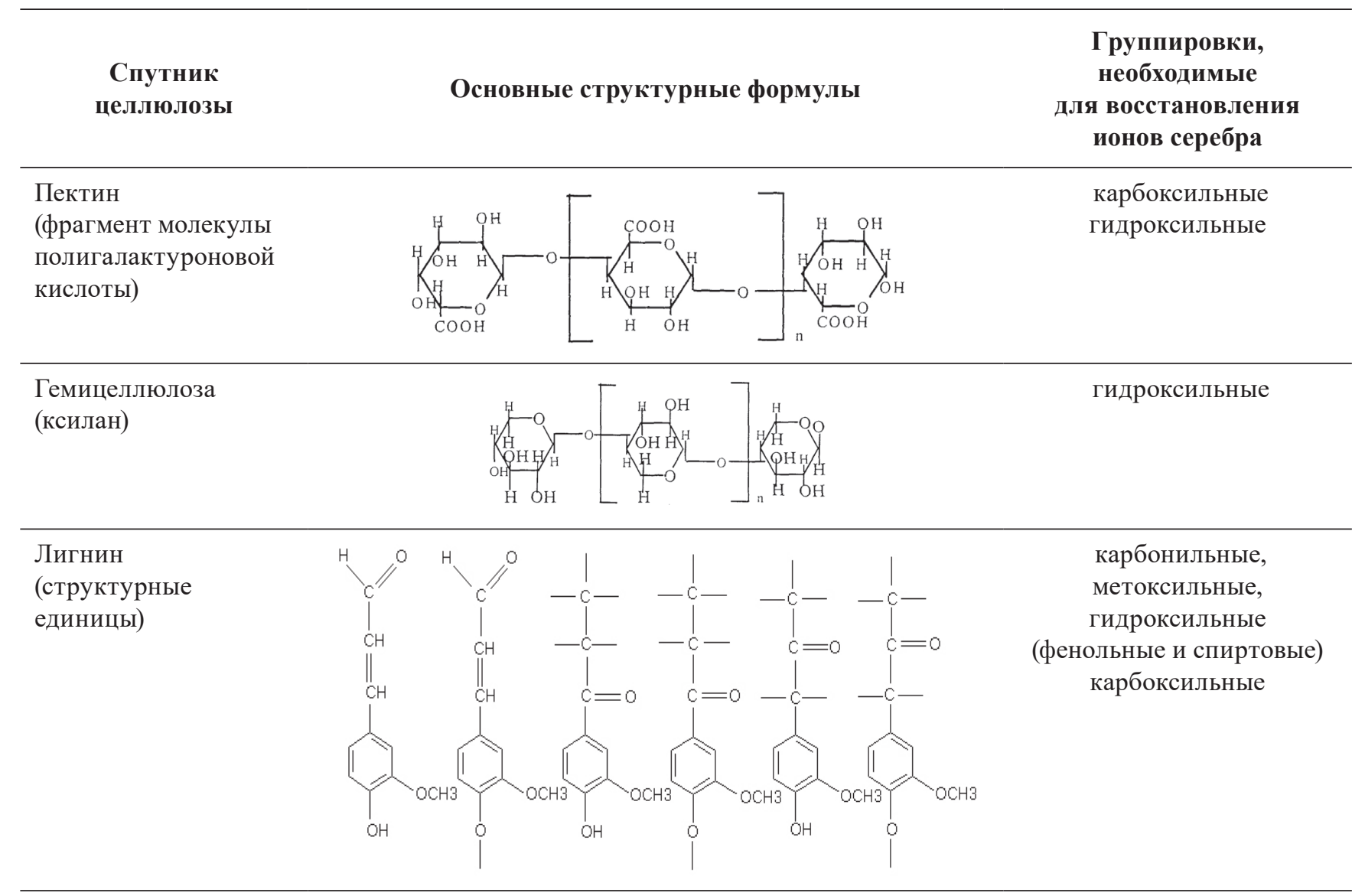

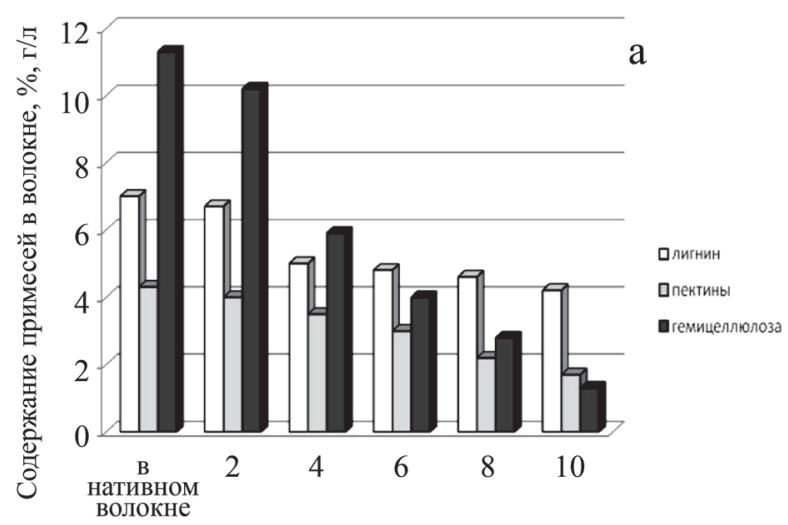

Концентрация $\mathrm{NaOH}$, г/л

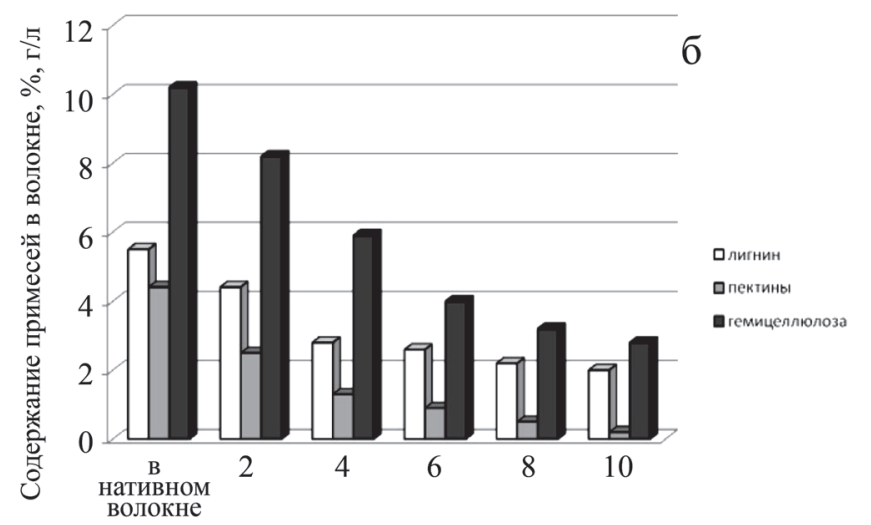

Концентрация $\mathrm{NaOH}$, г/л

Рис. 1. Зависимость содержания примесей в конопляном (а) и льняном (б) волокне от концентрации щелочи при обработке волокнистой массы

димо повышение концентрации щелочного агента до 10 г/л.

Определить возможное направление окислительно-восстановительной реакции между нитратом серебра и экстрактом из лубяных волокон можно, сопоставляя потенциалы сопряженных пар. Из- вестно, что реакция восстановления пройдет только в том случае, когда потенциал восстановителя в конкретных условиях (рН среды, температура) будет меньше потенциала окислителя.

Электродный потенциал окисленной формы вещества позволяет рассчитать уравнение Нерн- 
OВП

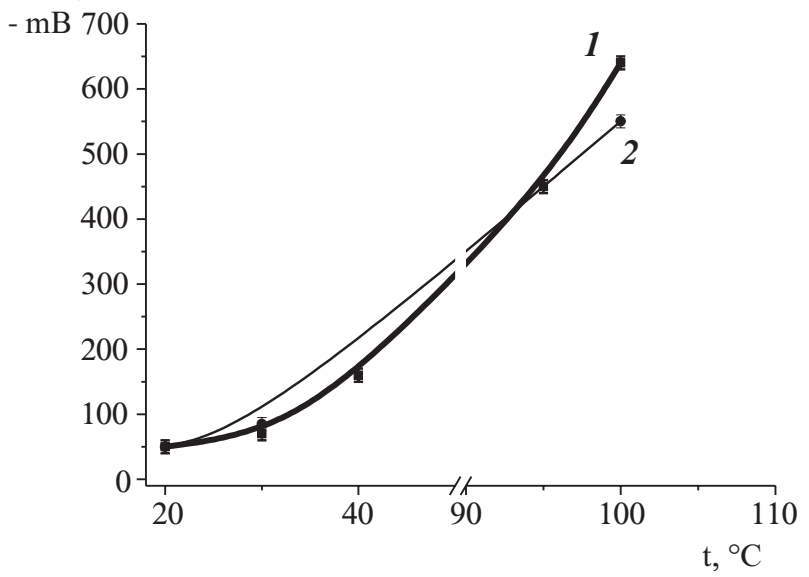

Рис. 2. Зависимость ОВП экстрактов конопляного (1) и льняного (2) волокон от температуры экстракции

ста [18]. Для реакции $\mathrm{Ag}^{+}+\mathrm{e} \leftrightarrow \mathrm{Ag}^{0}$ при концентрации нитрата серебра $0,6 \cdot 10^{-2}$ моль/л уравнение имеет вид:

$$
\begin{aligned}
& \mathrm{E}_{\mathrm{Ag}+/ \mathrm{Ago}}=\mathrm{E}_{\mathrm{Ag}+/ \mathrm{Ago}}^{\circ}+0,059 \cdot \lg \left[\mathrm{Ag}^{+}\right]= \\
& =0,80+0,059 \lg \left[0,6 \cdot 10^{-2}\right]=+0,66 \mathrm{~B},
\end{aligned}
$$

где $\mathrm{E}$ и $\mathrm{E}^{\circ}$ - электродный и стандартный электродный потенциал, В.

Окислительно-восстановительный потенциал (ОВП) экстрактов лубяных волокон в динамике изменения температуры экстракции от 20 до $100{ }^{\circ} \mathrm{C}$ приведен на рис. 4. Концентрация гидроксида натрия во всех растворах была 10 г/л. Резкое сниже- ние ОВП при увеличении температуры экстракции связано с практически полным удалением из волокон при высокотемпературной экстракции гемицеллюлозных соединений (рис. 1). Известно [19, 20], что наиболее высокими восстановительными свойствами из экстрагируемых примесей лубяных волокон обладают $\alpha$ - и $\beta$-глюкоза, ксилоза, альдопентозы, которые входят в состав гемицеллюлозных соединений лубяных культур.

Представленные на рис. 2 данные дают основание полагать, что образующийся в растворе комплекс редуцирующих веществ даже при низкой температуре экстракции может выступать в качестве восстановителя. Но чем больше разница Redox потенциалов пары восстановитель (раствор экстракта) $-\mathrm{Ag}^{+} / \mathrm{Ag}^{0}$, тем полнее и быстрее будет проходить реакция восстановления.

На рис. 3 представлены зависимости динамики формирования наночастиц серебра от выхода примесей в экстракт из лубяных волокон. Синтез НЧ проводили согласно методике, описанной в экспериментальной части. Чтобы избежать влияния щелочности на процесс восстановления нитрата серебра, экстракты перед реакцией синтеза нейтрализовали до $\mathrm{pH} 7,5-8,0$.

Известно, что восстановление ионов серебра качественно проявляется в окрашивании изначально бесцветного раствора до насыщенного желто-коричневого цвета и возникновении специфической полосы поглощения раствора в фиолетовой части видимого спектра $[21,22]$.

Для обоих видов лубяных волокон очевидна взаимосвязь эффективности процесса восстановления наночастиц серебра от количественного
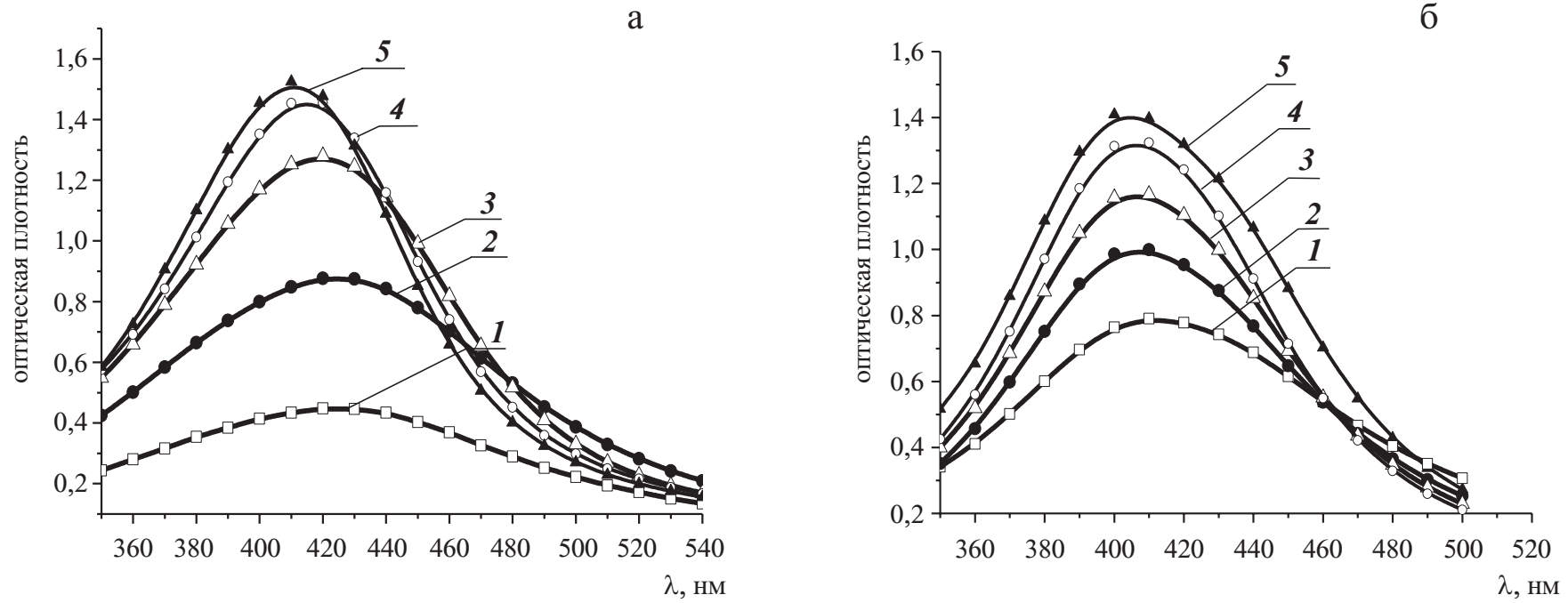

Рис. 3. Спектры поглощения НЧ серебра, синтезированных в присутствии экстракта, выделенного из конопляного волокна Диана (а) и льноволокна (б) при 100 С и концентрации гидроксида натрия, г/л:

$$
1-2 ; 2-4 ; 3-6 ; 4-8 ; 5-10
$$


содержания примесей в экстракте. При увеличении концентрации гидроксида натрия в варочном растворе от 2 до 10 г/л интенсивность максимума полосы поглощения повышается, а сама полоса сужается (кривые 1-5). Это связано как с получением более концентрированных экстрактов примесей волокна, так и с тем, что щелочь разрушает выделенные из волокна примеси, вызывает глубокие трансформации в их структуре, сопровождающиеся значительным увеличением функциональных групп, за счет которых происходит восстановление ионов серебра.

Введение соли серебра в экстракт конопли, полученный при концентрации щелочи 2 и 4 г/л приводит к появлению в электронных спектрах симметричной полосы поглощения с широким максимумом в области 420-440 нм слабой интенсивности (кривые 1 и 2, рис. 3a). Появление низкоинтенсивных полос поглощения вызвано образованием первичных центров металлического серебра [23]. В данных условиях уже начинается стадия восстановления $\mathrm{Ag}^{+}$, но оно не получает существенного развития и число образующихся восстановленных центров $\operatorname{Ag}(0)$ незначительно. По мере увеличения концентрации щелочного агента от 6 до 10 г/л и, соответственно, экстрагируемых примесей, на электронных спектрах формируется интенсивная симметричная полоса выраженной колоколообразной формы с $\lambda_{\text {max }} 400-420$ нм (кривая 5, рис. 3), обусловленная плазмонным резонансом наночастиц серебра [24].

Напротив, при химической модификации льноволокна даже при низкой концентрации щелочного агента 2 г/л образующийся в растворе комплекс редуцирующих веществ за счет извлечения примерно равных количеств гемицеллюлозы, пектинов и лигнина (рис. 1 б) может выступать в качестве восстановителя (кривая 1, рис. 3б). Увеличение концентрации гидроксида натрия в варочном растворе от 4 (кривая 2) до 10 г/л (кривая 5) приводит к значительному увеличению функциональных групп, способных восстанавливать серебро. Наибольший вклад в восстановительную способность системы, выделенной из льноволокна, преимущественно вносят пектиновые соединения и гемицеллюлоза. На электронных спектрах по мере нарастания в системе a

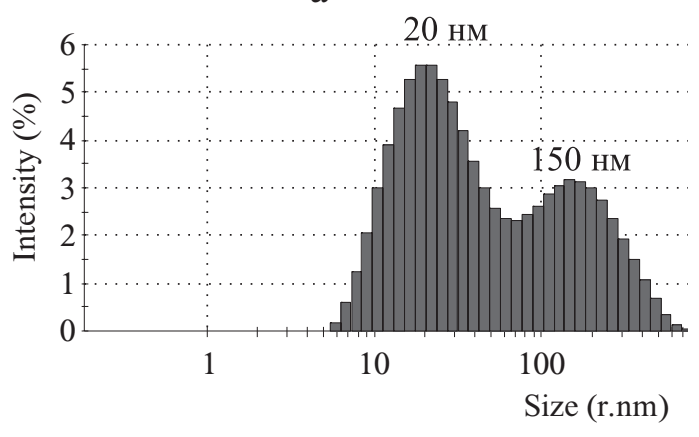

6

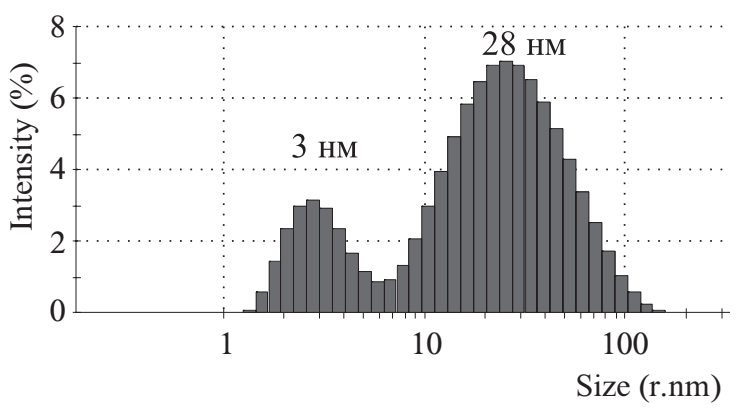

Рис. 4. Диаграмма распределения НЧ по размерам в системе Аg - экстракт конопляного волокна Диана, полученных при $100{ }^{\circ} \mathrm{C}$

Концентращия гидроксида натрия, г/л : $a-2 ; \sigma-10$

a

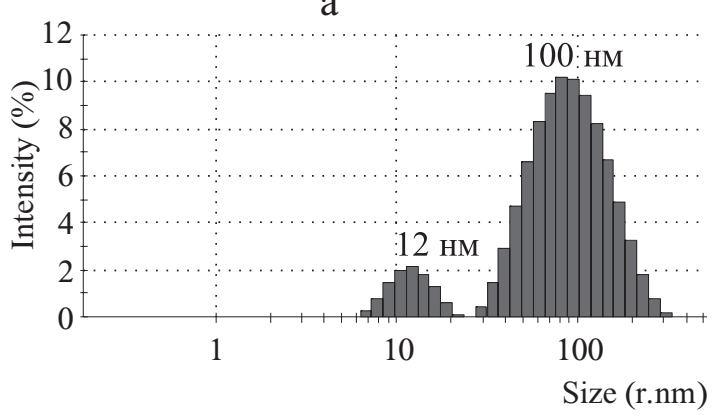

6

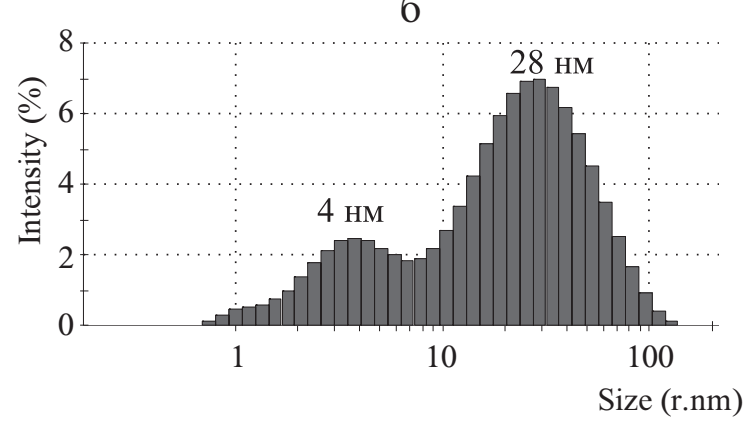

Рис. 5 Диаграмма распределения НЧ по размерам в системе Аg - экстракт льноволокна, полученных при $100{ }^{\circ} \mathrm{C}$

Концеентрайия гидроксида натрия, г/л : $а-2 ; \sigma-10$ 
функциональных групп наблюдается рост интенсивности полос поглощения с $\lambda_{\max } 400$ нм, что свидетельствует о высокой скорости восстановительных процессов и получении большого числа наночастиц серебра малого размера.

Данный вывод подтверждается диаграммами распределения наночастиц по размерам, полученными методом фотонной корреляционной спектроскопии (рис. 4, 5).

Анализ спектральных кривых фракционного распределения показывает, что они являются бимодальными. В препарате серебра, полученном в малощелочном экстракте из лубяных волокон (рис. 4a, 5a), преимущественно содержатся частицы с радиусом (включая оболочку стабилизатора) более 100 нм. Синтез в сильнощелочных экстрактах исследуемых лубяных волокон позволяет получать частицы малого размера, не более 30 нм (рис. 4б, 5б).

Таким образом, выявленные особенности формирования наночастиц серебра на основе выбора оптимальных условий экстракции природных примесей лубяных волокон позволяют осуществлять эффективное восстановление и стабилизацию наночастиц серебра и могут представлять интерес при разработке новых антимикробных препаратов.

\section{Оченка антибактериальной активности целлюлозных материалов}

Количественную оценку антимикробной активности золей, синтезированных в присутствии экстрактов, выделенных из лубяных волокон при $100{ }^{\circ} \mathrm{C}$ и концентрации гидроксида натрия 4 и 10 г/л, в отношении основных возбудителей хи- рургической инфекции (Staphylococcus aureus u Escherichia coli) определяли по зоне ингибирования роста тест-культур вокруг образцов. Данные, наглядно подтверждающие зависимость антимикробной активности от условий получения экстракта и, соответственно, от количества группировок, способных восстанавливать ионы серебра, отражены на фото табл. 3.

Представленные фото свидетельствуют, что золи серебра, синтезированные в экстракте, полученном при высокой концентрации щелочи, обладают высокой активностью по отношению к данным видам микрофлоры. В случае Staphilococcus зоны ингибирования вблизи НЧ, полученных в экстрактах при концентрации щелочного агента 10 г/л, составляют 5,0-12,0 мм, в случаe Escherichia coli - 2,4-4,0 мм. Золи, полученные в менее концентрированном экстракте, проявляют значительно меньшую активность по отношению к Staphilococcus и лишь бактериостатическую к Escherichia coli.

Интересной представлялась возможность исследовать антимикробную активность суровой и отбеленной целлюлозной ткани, обработанной синтезированными золями по зонам задержки роста тест-культур. В качестве последних использовали предварительно выращенные на скошенном агаризованном мясопептонном агаре суточные тест-культуры микроорганизмов (кишечной палочки Escherichia coli M-17 - грамотрицательная культура и золотистого стафилококка Staphylococcus aureus 6538-P ATCC=209-P FDA - грамположительная культура) и штамма дрожжеподобных микроскопических грибов - кандида альбиканс Candida albicans CCM 8261 (ATCC 90028).

\section{Антимикробная активность синтезированных золей}

Условия экстракции:

T, ${ }^{\circ} \mathrm{C} /$ конц. $\mathrm{NaOH}$, г/л

\section{Лубяное волокно}

\begin{tabular}{llll}
\hline Конопля & Лен & Конопля & Лен \\
\hline
\end{tabular}

Тест культура

Staphylococcus aureus

Escherichia coli
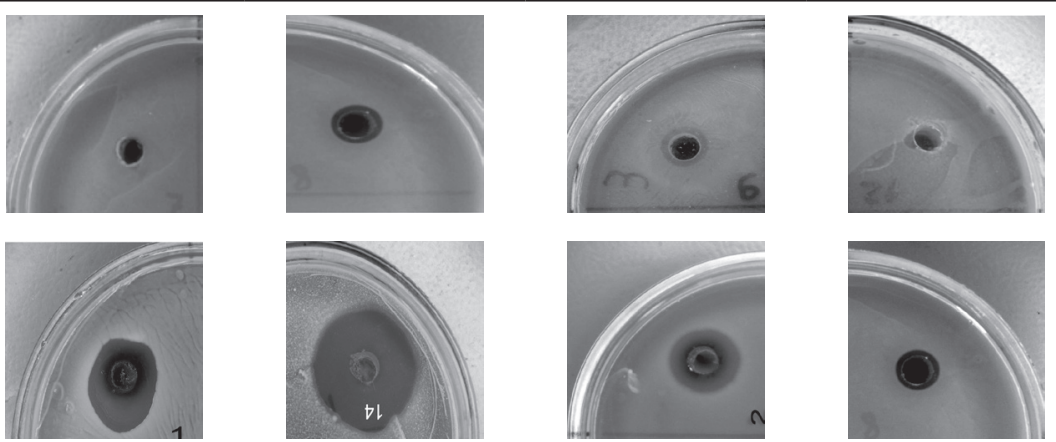
Антимикробная активность целлюлозной ткани, обработанной синтезированными золями

\begin{tabular}{ccccc}
\hline & $\begin{array}{c}\text { Концентрация } \\
\text { № }\end{array}$ & \multicolumn{2}{c}{ Зоны задержки роста тест-культур вокруг полимерной матрицы, мм } \\
\cline { 3 - 5 } & $\begin{array}{c}\text { при получении } \\
\text { экстракта, г/л }\end{array}$ & Staphylococcus aureus & Escherichia coli & Candida albicans \\
\cline { 3 - 5 } & 2 & $1-2$ & 0, нет роста под образцом & $2-3$ \\
2 & 8 & $1-2$ & $2-3$ & $1-2$ \\
3 & 10 & $4-5$ & $3-4$ & $3-4$ \\
\hline
\end{tabular}

В табл. 4 приведены данные зон ингибирования роста тест-культур вокруг образцов отбеленной хлопчатобумажной ткани, обработанной синтезированными золями, полученными при разной концентрации гидроксида натрия.

Представленные данные свидетельствуют, что зоны ингибирования вблизи образцов ткани, обработанной НЧ серебра, полученными восстановлением в сильнощелочном экстракте (образец 3) и имеющими размер частиц серебра не больше 30 нм, для всех исследуемых тест-культур достаточно высокие и составляют 3-5 мм. Ткань, обработанная золями серебра, синтезированными в экстракте с концентрацией гидроксида натрия 2 и 8 г/л (образцы 1 и 2), по антимикробному действию уступает действию образца №3. Образец № 1 по отношению к Escherichia coli проявляет лишь бактериостатическую активность. Об этом свидетельствует тот факт, что при практически нулевых зонах под образцом роста микрофлоры не обнаружено.

Исследование эффективности синтезированных золей для биозащиты суровой целлюлозной ткани также показали зависимость от условий синтеза. Фото на рисунке 3 наглядно это подтверждают.

В условиях культивирования естественного комплекса почвенной микрофлоры на незащищенной ткани (рис. 3а) появляются пигментные пятна, паутинообразные пленки, грубые объемные образования, свидетельствующие о колонизации её поверхности микробными культурами и об их приспособленности к существованию на данном субстрате. Это приводит к полной потере эксплуатационных свойств текстильного материала.

На ткани, модифицированной синтезированным серебряным золем, полученным в низкоконцентрированном экстракте (рис. 3б), при отсутствии нарушения структуры наблюдается пигментация, что свидетельствует о недостаточно хорошей защите материала. Напротив, у ткани, обработанной золем, синтезированным в экстракте,

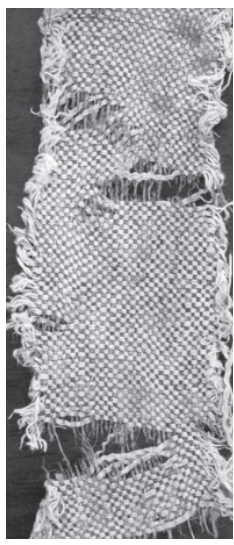

$\boldsymbol{a}$

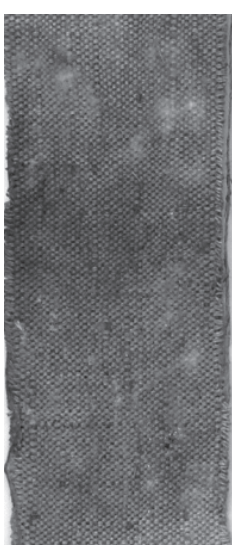

б

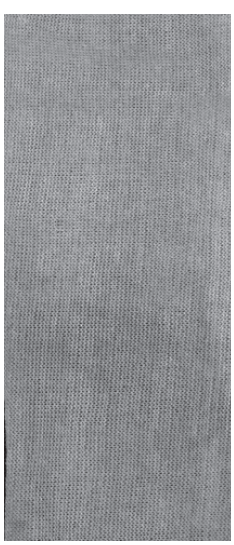

$\boldsymbol{B}$
Рис. 6. Оценка биозащиты суровой целлюлозосодержащей ткани после контакта с почвенной микрофлорой:

$\boldsymbol{a}$ - ткань без обработки; $\boldsymbol{\sigma}$ - обработана НЧ серебра, полученными восстановлением в экстракте с кониентрацией щелочи 2 г/л; в - обработана НЧ серебра, полученныли восстановлением в экстракте с концентрацией щелочи 10 г/л

полученном при высокой концентрации щелочи (рис. 3в), в аналогичных условиях культивации подобных изменений нет, что свидетельствует о сохранности эксплуатационных характеристик материала.

Следовательно, регулированием процессов синтеза нанообъектов можно в значительной степени изменять антимикробную активность препаратов серебра и обработанных ими текстильных изделий с целью придания лечебных и профилактических свойств или обеспечения эффективной защиты целлюлозных текстильных материалов от биоразрушения.

\section{Выводы}

1. Методами спектрофотометрии, фотонной корреляционной спектроскопии и визуальным 
наблюдением исследован процесс синтеза ультрадисперсных частиц серебра в присутствии сопутствующих природных примесей лубяных волокон, выделенных из него в процессе щелочной высокотемпературной обработки. Определено влияние состава экстракта на динамику формирования стабильных НЧ металла.

2. Получена зависимость антимикробной активности золей в отношении тест-культур Staphylococcus aureus и Escherichia coli от условий получения экстракта.

3. Показана эффективность золей, синтезированных в высококонцентрированном экстракте, для антимикробной отделки отбеленной хлопчатобумажной ткани и биозащиты суровой целлюлозной ткани.

Исследования выполнены в рамках Государственного задания Института химии растворов им. Г.А. Крестова РАН (проект № 01201260484) с использованием приборной базы ЦКП «Верхневолжский региональный иентр физико-химических исследований».

\section{Лuтература}

1. Серебро в медицине, биологии и технике: сборник трудов. - Новосибирск: Вектор-Бест, 1996. 224 с.

2. Ярмоленко М.А. Наукоемкие технологии. 2011. №5. C. 26-34.

3. Арчаков А.И. Биомедицинская химия. 2006. №6. С. 529-546.

4. Кричевский Г.Е. Зеленые и природоподобные технологии - основа устойчивого развития для будущих поколений. T.II Зеленые нанотехнологии. Зеленый биосинтез наночастиц металлов. Зеленый текстиль. - М. Грин Принт, 2019. 308 с.

5. Грищенко Л.А. Журнал общей химии. 2006. Т. 76. №7. C. 1159-1165.

6. Макаров В.В., Лав А., Синицына О.В., Макарова С.С., Яминский И.В., Тальянский М.Э., Калинин Н.О. Acta naturae. 2014. T. 6. № 1 (20). C. 37-47.

7. Varma R.S., Nadagouda M.N. Green Chem. 2008. V. 10. P. 859-862.
8. Ravindra S., Murali Mohan Y., Narayana Reddy N., Mohana Raju K. Colloids and Surfaces A: Physicochem. Eng. Aspects. 2010. V. 367. P. 31-40.

9. Begum N.A., Mondal S., Basu S., Laskara R.A., Mandal D. Colloids and Surfaces B: Biointerfaces. 2009. V. 71. P. $113-118$.

10. Белова М.М., Шипунова В.О., Котельникова П.А., Бабёнышев А.В., Рогожин Е.А., Чередниченко М.Ю., Деев С.М. Acta naturae. 2019. Т. 11. № 2 (43). С. 47-53.

11. Дымникова Н.С. Ерохина Е.В., Морыганов А.П. Перспективные материалы. 2017. №6. С. 29-38.

12. Григорьев П.Н., Хисамиева Г.А., Оболенская А.В., Ельницкая 3.П., Леонович А.А. Лабораторные работы по химии древесины и целлюлозы: Учебное пособие для вузов. М.: Экология. 1991. 320 с.

13. Аналитический контроль производства исскуственных волокон. Справочное пособие/Под ред. А.К. Дибровой, В.С. Матвеева. М.: Химия. 1986. 136 с.

14. Фридлянд Г.И. Отделка льняных тканей. М.: Легкая и пищевая промышленность. 1982. 430 с.

15. Мельников Б.Н., Захарова Т.Д., Кириллова М.Н. Физико-химические основы процессы отделочного производства. М.: Легкая и пищевая промышленность. $1982.280 \mathrm{c}$.

16. Стокозенко В.Г., Морыганов А.П., Ларин И.Ю., Воронина Е.Р. Химия растительного сырья. 2017. №2. C. $143-148$.

17. Стокозенко В.Г., Неманова Ю.В. Известия ВУЗов. Химия и химическая технология. 2009. Т. 52. № 5 . C. 56-59.

18. Крешков А.П. Основы аналитической химии. М.: Химия. 1971. Т. 2. $456 \mathrm{c.}$

19. Lepilova O.V., Aleeva S.V., Koksharov S.A. Eurasian Chemico-Technological Journal. 2017. V. 19. N 1. P. 31-40.

20. Lepilova O.V., Aleeva S.V., Koksharov S.A. Org. Chem. 2012. V. 48. N 1. P. 83-88.

21. Венедиктов Е.А., Падохин В.А. Журнал прикладной химии. 2008. Т. 81. Вып. 11. С. 1925-1928.

22. Крутяков Ю.А., Кудринский А.А., Оленин А.Ю., Лисичкин Г.В. Успехи химии. 2008. Т. 77. С. 242-269.

23. Низамов Т.Р., Евстафьев И.В., Оленин А.Ю., Лисичкин Г.В. Коллоидный журнал. 2014. Т. 76. №4. C. $513-518$.

24. Дымникова Н.С., Ерохина Е.В., Морыганов А.П. Российский химический журнал. 2019. Т. LXIII. №2. C. $45-51$. 